\title{
Light my fire
}

Citation for published version (APA):

van Marken Lichtenbelt, W. (2014). Light my fire: leven buiten de comfort zone. Maastricht University. https://doi.org/10.26481/spe.20140919wml

Document status and date:

Published: 19/09/2014

DOI:

10.26481/spe.20140919wml

Document Version:

Publisher's PDF, also known as Version of record

\section{Please check the document version of this publication:}

- A submitted manuscript is the version of the article upon submission and before peer-review. There can be important differences between the submitted version and the official published version of record.

People interested in the research are advised to contact the author for the final version of the publication, or visit the DOI to the publisher's website.

- The final author version and the galley proof are versions of the publication after peer review.

- The final published version features the final layout of the paper including the volume, issue and page numbers.

Link to publication

\footnotetext{
General rights rights.

- You may freely distribute the URL identifying the publication in the public portal. please follow below link for the End User Agreement:

www.umlib.nl/taverne-license

Take down policy

If you believe that this document breaches copyright please contact us at:

repository@maastrichtuniversity.nl

providing details and we will investigate your claim.
}

Copyright and moral rights for the publications made accessible in the public portal are retained by the authors and/or other copyright owners and it is a condition of accessing publications that users recognise and abide by the legal requirements associated with these

- Users may download and print one copy of any publication from the public portal for the purpose of private study or research.

- You may not further distribute the material or use it for any profit-making activity or commercial gain

If the publication is distributed under the terms of Article $25 \mathrm{fa}$ of the Dutch Copyright Act, indicated by the "Taverne" license above, 


\section{Maastricht University}

Prof. dr. Wouter van Marken Lichtenbelt

Faculty of Health, Medicine and Life Sciences

\section{Light my Fire - Leven buiten de comfort zone}

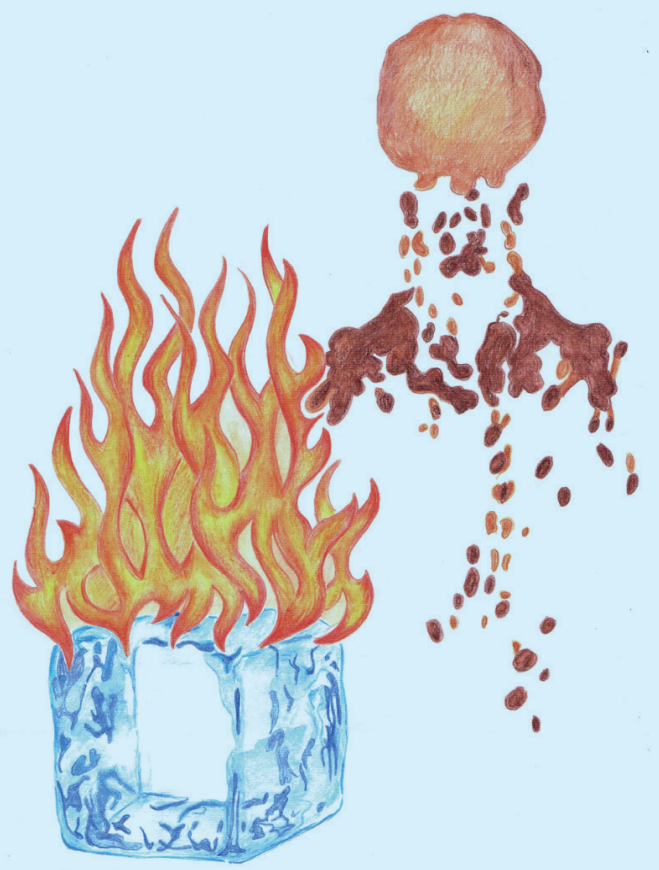


Light my Fire -

\section{Leven buiten de comfort zone}




\section{Colofon}

Design \& print: Canon Business Services, Maastricht

ISBN: 978-90-5681-447-2

NUR: 874

All rights reserved. No part of this publication may be reproduced, modified, stored in a retrieval system or made public without the prior written permission of the author or publisher. 


\section{Light my Fire - Leven buiten de comfort zone}

\section{Rede}

Uitgesproken bij de aanvaarding van het ambt van bijzonder Hoogleraar Ecologische Enegetica en Gezondheid aan de Faculty of Health, Medicine and Life Sciences

Maastricht, 19 september 2014

Door Prof. dr. Wouter van Marken Lichtenbelt 
Mevrouw de Pro-rector, zeer geachte dames en heren, vrienden en familieleden,

Hoe voelt $u$ zich? Heeft $u$ het te warm, te koud of bent $u$ comfortabel? Ik wil graag een kleine inventarisatie uitvoeren. U heeft net, bij binnenkomst van het cortège, even kunnen oefenen met gaan staan en weer gaan zitten. Willen nu degenen die het te warm hebben gaan staan? Ik zie, dat is ongeveer de helft van $u$. Dank, $u$ kunt weer gaan zitten. Wil iedereen die het comfortabel heeft gaan staan? Dat is ruim de helft. Mooi. Dan tenslotte: willen degenen die het te koud hebben opstaan. Ondanks het warme weer zijn er toch een paar personen die het te koud hebben; niet geheel onverwachts betreft het vrouwen. $U$ kunt gaan zitten.

$U$ ziet het, zo'n kleine inventarisatie geeft al interessante informatie. Niet iedereen voelt zich hetzelfde. Er is een groot verschil tussen personen. De een heeft het te warm, de ander voelt zich comfortabel. En er zijn mensen die het warm hebben en zich toch comfortabel voelen. Deze individuele verschillen worden veroorzaakt door verschillen in thermoregulatie. Daarover gaat deze oratie. En wat mijzelf betreft: nooit eerder heb ik op deze manier in het brandpunt van de belangstelling gestaan. Ik krijg het er warm van!

\section{Inleiding}

Jaren geleden bij een bezoek aan het Muiderslot zag ik in een van de grote zalen een bank bij de open haard staan. Nu zou je denken dat zo'n groot kasteel wel over het nodige comfort zou beschikken, maar's winters kon het zelfs binnen echt koud zijn. Dat de bank bij de open haard stond is logisch; lekker warm. Maar als de haard goed trok, ontstond er tocht en op de bank zittend kreeg je een koude rug. De bank was zo gemaakt dat de leuning kon omklappen, zodat keuvelende dames na een half uur van voren geroosterd en van achteren bevroren, de leuning konden omklappen om vervolgens met de rug naar het vuur te gaan zitten.

Waarschijnlijk voelde deze wisseling niet eens onaangenaam.

Laten we naar wat primitievere omstandigheden kijken. In de jaren 50 heeft Per Fredrick Scholander de Aboriginals bestudeerd (Scholander et al., 1958). Deze mensen sliepen naakt in de woestijnen van Australië, waar het overdag snikheet is, maar de temperatuur's nachts tot nabij het vriespunt kan zakken. Zij maakten bij het overnachten in de koude woestijn gebruik van een klein lokaal vuur. Ondanks de kou rilden ze niet en sliepen ze goed. 
De westerse mensen, die ter vergelijking met de proef meededen, rilden en brachten daardoor de nacht slapeloos door.

Het zal duidelijk zijn dat in de loop van de tijd onze thermische omgeving drastisch is veranderd. De CV slaat automatisch aan en het hele huis wordt verwarmd in de winter. Tegenwoordig beschikken steeds meer gebouwen en huizen over een airconditioning in de zomer. 's Zomers en 's winters worden vermeende comfortabele temperaturen ingesteld.

Onze omgeving is in honderd jaar enorm veranderd. Wij zelf zijn de laatste duizenden jaren niet noemenswaardig veranderd. Evolutie van de mens werkt veel trager.

Eigenlijk leven we, biologisch gezien, als oermensen in een moderne omgeving. Hebben we wel genoeg aanpassingsvermogen? Met andere woorden, is een constante comfortabele omgevingstemperatuur gezond? Is dat, naast te veel eten en te weinig beweging, een reden van het voorkomen van steeds meer te dikke mensen?

Bij Humane Biologe doen we veel onderzoek naar overgewicht. Dat is tegenwoordig een van de grootste gezondheidsproblemen. Dik zijn leidt tot allerlei complicaties, zoals suikerziekte en hart- en vaat-ziektes. Onderzoek van de afgelopen tientallen jaren is gericht geweest op een verandering van leefstijl (minder eten, meer bewegen) of op farmacologische interventie om overgewicht tegen te gaan. Helaas heeft het onderzoek niet tot resultaat geleid: er bestaat geen pil tegen overgewicht en er is geen geschikt leefstijlprogramma dat langdurig werkt.

Ik denk dat een belangrijke factor, namelijk de omgevingsconditie, te weinig aandacht heeft gekregen. De mens in zijn omgeving, daar gaat het om. Een belangrijke omgevingsfactor is de temperatuur. Over de moderne thermische omgeving, d.w.z. ons binnenklimaat in huizen en kantoren, zal ik in het tweede deel spreken. Eerst ga ik het hebben over de thermoregulatie van de mens zelf.

Tijdens mijn verhaal wil ik met $u$ delen hoe het onderzoek op mijn pad is gekomen. Als onderzoeker begeef je je op onbekend terrein. Je kunt twee dingen doen. Je kunt de diepte ingaan. Een bepaald proces kiezen en er steeds meer details over verzamelen en hopen dat meer details het inzicht vergroten. Je kunt ook de breedte ingaan. Dat betekent: in welke context doet zich iets voor? Dan is het verstandig dat je op zoek gaat naar raakvlakken met andere onderzoeksgebieden. Dat laatste is, al dan niet bewust, wat ik vooral gedaan heb, het advies volgend van mijn promotor, Professor Rudi Drent. Hij spoorde mij tijdens mijn promotieonderzoek al aan tot een samenspel tussen landbouwwetenschappen en biologie. 


\section{Thermoregulatie en energiebalans}

Bij thermoregulatie speelt de energiebalans een belangrijke rol. Deze balans wordt bepaald door wat er aan energie in gaat en hoeveel energie we uitgeven. De energie die er in gaat halen we uit de voeding. Te veel aan energie-inname slaan we op als lichaamsvet.

De energie-uitgave is afhankelijk van hoeveel energie je gebruikt in rust, voor het onderhoud van je lichaam. Daarnaast speelt ook mee hoeveel je beweegt (sporten bijvoorbeeld). Tenslotte speelt ook de omgevingstemperatuur een rol.Opde lange termijn moet de energiebalans gelijk zijn aan nul anders kom je aan of val je af.

De meeste energie die wordt gebruikt in het lichaam wordt omgezet in warmte. De energie-uitgave is dus vrijwel identiek aan de warmteproductie. Die warmte moet je afstaan aan de omgeving, anders stijgt je lichaamstemperatuur te veel. Thermoregulatie gaat over de balans tussen warmte productie en warmte verlies.

\section{De groene leguaan}

Als eerste voorbeeld van thermoregulatie en de link met de energiehuishouding geef ik resultaten van mijn promotie-onderwerp: de groene leguaan, een reptiel van Curaçao (van Marken Lichtenbelt, 1991). Tijdens dit onderzoek keek ik hoe efficiënt de dieren met hun energie omgingen. Wat kunnen ze uit hun voedsel halen dat ze met zoveel moeite vergaren in de natuur en hoe geven ze die energie uit? Daarvoor had ik technieken uit de landbouwwetenschappen nodig, bijvoorbeeld voor de voedselverteringsproeven, en gegevens uit het veld.

Anders dan bij de mens heeft een leguaan geen constante temperatuur. Als het buiten koud is wordt het dier ook koud. Dan gaan alle lichaamsreacties langzamer en gebruikt hij minder energie. Als hij warm is gaat alles wat sneller, maar kost hem dat ook meer energie. Leguanen leven in de tropen om op temperatuur te kunnen blijven.

De dieren kunnen hun temperatuur regelen door meer of minder in de zon te gaan zitten. De luchttemperatuur overdag is ongeveer $27^{\circ} \mathrm{C}$. We hebben met behulp van leguanenmodellen kunnen laten zien dat de maximale temperatuur van een zonnende leguaan tot ruim $48{ }^{\circ} \mathrm{C}$ zou kunnen oplopen. Bij vrij levende dieren die van een temperatuurzender waren voorzien, bleek dat leguanen hun lichaamstemperatuur regelen op maximaal $36{ }^{\circ} \mathrm{C}$. Niks koudbloedig dus! Een van de interessantste bevindingen uit dit deel van het onderzoek, is dat die lichaamstemperatuur verschilde per dier. Er waren grote individuele verschillen. Het bleek dat de lichaamstemperatuur werd afgestemd op de voedselinname. Dieren 
die minder voedsel konden bemachtigen in de natuur kozen een lagere temperatuur dan $36{ }^{\circ} \mathrm{C}$ en bespaarden zo op hun energie uitgaven! De leguaan regelt met zijn thermisch gedrag de energiebalans.

\section{De mens}

Maar hoe zit dat bij de mens? Kan de mens via thermoregulatie zijn energiebalans bijstellen? En hoe groot is de individuele variatie bij de mens? In tegenstelling tot de leguaan heeft de mens een veel constantere lichaamstemperatuur van ongeveer $37^{\circ} \mathrm{C}$. De leguaan spaart energie bij lage omgevingstemperaturen. Wij moeten in de kou juist actie ondernemen om de temperatuurvan $37^{\circ} \mathrm{C}$ te handhaven, bijvoorbeeld door te rillen. Dat kost extra energie, en dus moet je meer eten om op gewicht te blijven, in tegenstelling tot de leguaan.

$\mathrm{Er}$ is ook een energiezuinige manier om onze constante temperatuur te handhaven. Door niet de energie(warmte)productie te regelen, maar de warmteafgifte. We kunnen die via de huid regelen. Onze huid is eigenlijk een radiator en ons bloed het koelwater. Wij kunnen meer warmte afgeven door meer bloed naar de huid te leiden. $U$ herkent dat waarschijnlijk: als je het warm hebt zetten je bloedvaten uit en word je rood, terwijl in de kou je vingers blauw of zelfs kleurloos kunnen worden en koud aanvoelen. Het regelen van de warmteafgifte met doorbloeding van de huid lukt maar bij een klein temperatuurinterval. Bij de naakte mens is dat van 28 tot $32{ }^{\circ} \mathrm{C}$ en met kleren aan bijvoorbeeld van 20 tot $24^{\circ} \mathrm{C}$. Onder je kleding creëer je een warme laag waarbinnen je je comfortabel voelt. Binnen dat temperatuurinterval is het energiegebruik minimaal.

Deze zone noemen we de thermoneutrale zone (TNZ)(figuur 1) (Kingma et al., 2012). In de grafiek is deze zone groen gekleurd. Bij hogere en bij lagere omgevingstemperaturen gaat het energiegebruik (de warmteproductie) van het lichaam omhoog. 


\section{thermoneutrale zone}

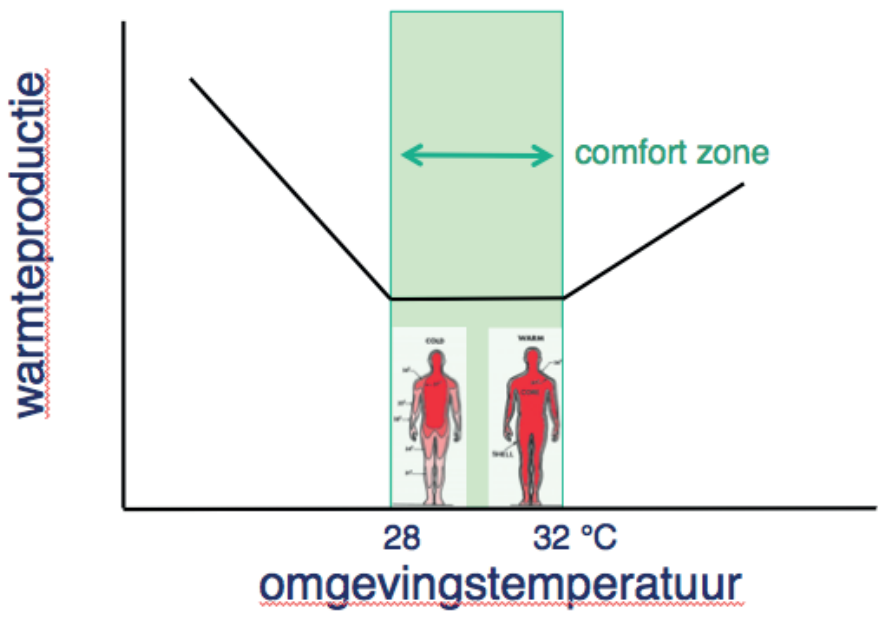

Figuur 1. De thermoneutrale zone en de comfort zone.

Binnen de TNZ voelt men zich bij benadering comfortabel. Dat interval noemen we de comfortzone. Buiten de TNZ wordt het interessant. In de kou gaat je energiegebruik omhoog. In een warme omgeving gebeurt dat ook, maar daar ga ik nu niet op in; dat komt in een vervolg onderzoek aan de orde. In de kou kan het energiegebruik omhoog door te rillen, maar ongeveer tien jaar geleden hebben we aangetoond dat het ook zonder rillen kan. Mits het niet te koud is.

Onze metingen voeren we uit in speciale respiratiekamers van het Metabolic Research Unit Maastricht (MRUM). Hier kunnen we de omgevingstemperatuur nauwkeurig regelen en de lichaamstemperatuur meten. Bovendien kunnen we aan de hand van het zuurstofgebruik en de kooldioxide-productie de warmteproductie van het lichaam meten.

De resultaten van onderzoek van Marieke van Ooijen laten het energiegebruik van een proefpersoon in een koude omgeving zien. Eerst treedt extra warmteproductie op zonder rillen en pas na enige tijd gaan de proefpersonen rillen. We vonden deze resultaten interessant, omdat we temperaturen waarbij we net niet rillen, ook in onze dagelijks leven, tegenkomen. 


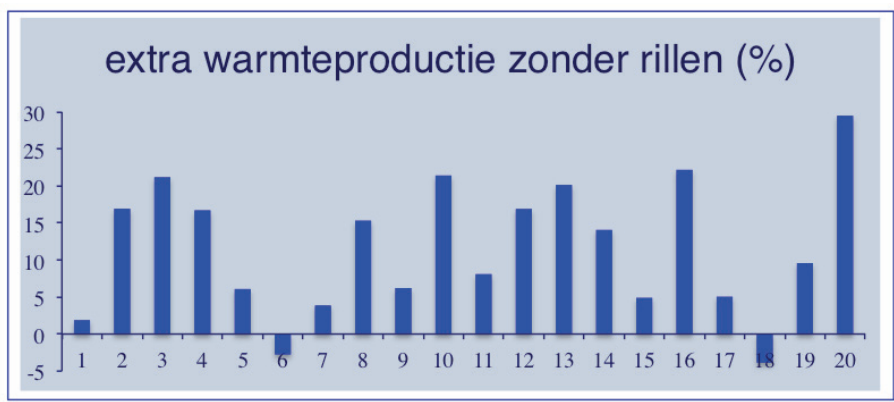

\section{0 proefpersonen}

Figuur 2. Warmte productie in de kou zonder te rillen bij 20 proefpersonen. De resultaten staan weergegeven als percentage ten opzichte van het rustmetabolisme in een thermoneutrale omgeving.

De bijdrage van warmteproductie zonder te rillen kan groot zijn, maar varieert van persoon tot persoon van o tot ruim $30 \%$ extra warmteproductie ten opzichte van thermoneutraal (figuur 2). Bij sommige mensen is de bijdrage dus klein, terwijl die bij anderen deze juist groot is. Er zijn grote individuele verschillen. Dat is interessant en een leidraad geworden in ons onderzoek. Het is ook relevant, want zoals we straks zullen zien is onze dagelijkse leefomgeving ingericht op de gemiddelde mens. En die bestaat helemaal niet zoals u ziet!

Uit onderzoek van Sander Wijers bleek dat mensen met overgewicht een relatief lage extra warmteproductie in de kou hebben. Onderzoek uitgevoerd door Boris Kingma liet bovendien zien dat veel ouderen zelfs een verminderde warmteproductie hebben, net als de twee proefpersonen no. 6 en 18 in figuur 2. Zij gedragen zich een beetje als reptielen. Hun lichaam koelt af en daarmee gaan ze juist minder energie gebruiken!

\section{Bruin vet}

Welk weefsel is verantwoordelijk voor deze warmteproductie in de kou, zonder dat je rilt? Het is al heel lang bekend dat winterslapers en kleine knaagdieren hiervoor het weefsel bruin vet hebben. Na de winterslaap moeten de dieren kunnen opwarmen en daarvoor gebruiken ze bruin vet. Ook is het bekend dat baby's bruin vet hebben. Baby's zijn klein en koelen zonder moederwarmte gemakkelijk af. Om dan op temperatuur te blijven gebruiken ze het bruine vet. Volgens de leerboeken kwam bruin vet niet voor bij de volwassen mens. In 2009 toonden we echter aan dat actief 
bruin vet ook bij volwassenen aanwezig is (van Marken Lichtenbelt et al., 2009). Dat was groot nieuws, want bruin vet heeft, althans bij dieren, een grote capaciteit om warmte te produceren en mogelijk nog andere gunstige effecten op de gezondheid.

Maar wát is het nu precies dat bruine vet en waarom kan bruin vet gezond zijn? Het witte vet kent $u$ vast, misschien zelfs aan den lijve... De cellen zien er witachtig uit; ze zitten bomvol vet (figuur 3) en zorgen voor de opslag van energie in het lichaam. Daar is op zich niets mis mee. Reserve energie kan heel belangrijk zijn, bijvoorbeeld tijdens ziekte of als er voedseltekort is. Een te veel aan wit vet is daarentegen niet gezond.
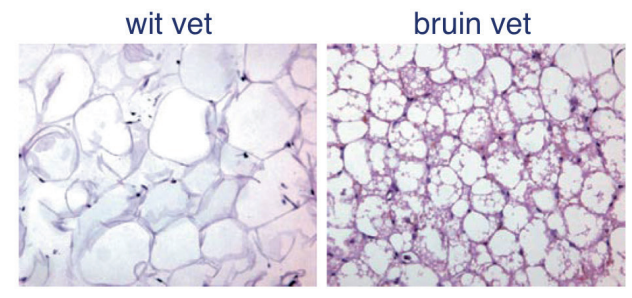

energie-opslag
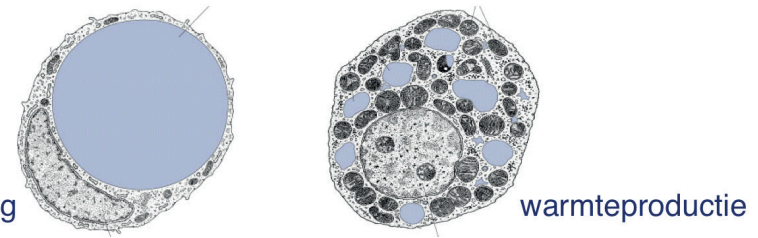

Figuur 3. Witte vetcellen en bruine vetcellen.

Bruin vet zorgt juist voor extra warmteproductie in een koude omgeving. Het is eigenlijk een inwendig kacheltje van het lichaam dat in de kou aanslaat. De bruine vetcel ziet er heel anders uit dan de witte vetcel. Ook hier is vet opgeslagen, maar veel minder. Het vet zit in kleine bolletjes. In de rest van de bruine vetcel zitten vooral heel veel mitochondriën. Dat zijn energiefabriekjes van de cel waarin de warmte wordt geproduceerd. Het bruin vetweefsel is heel goed doorbloed. Door de vele mitochondriën in de cellen en de sterke doorbloeding ziet het er roodbruin uit. Vandaar de naam. Hoe hebben we dat bruine vet opgespoord? Dit is weer een mooi voorbeeld van een samenwerking tussen twee disciplines; de breedte in. In de tijd dat we onderzoek deden naar de effecten van kou sprak ik toevallig Professor Jaap Teule van de afdeling Nucleaire Geneeskunde. Een veelgebruikte techniek om bij patiënten kanker op te sporen is 
de zogenaamde PET/CT scan. Professor Teule vertelde me dat ze met die scans regelmatig last hadden van bruin vet. Voor de scan wordt een radioactieve merkerstof ingespoten die aangeeft of er een gezwel aanwezig is, zoals bij een longtumor. De merkerstof is een soort suiker die via het bloed naar de weefsels gaat die suiker gebruiken en daar wordt die merkerstof dan opgeslagen. Met de PET/CT scan kan je dat daarna zichtbaar maken. De hersenen gebruiken vrijwel alleen suikers als brandstof en tumoren ook. Maar sommige patiënten, die het wat koud hadden, lieten merkerstofopname zien in gebieden achter de sleutelbenen en in de hals. Eerst werd deze opname toegeschreven aan gespannen spieren. Het bleek bruin vet te zijn. Men zag het als de patiënt het koud had. De kou zette het bruin vet "aan".

We zijn hierom gaan samenwerken met Nucleaire Geneeskunde. Door mensen bloot te stellen aan een koele omgeving (zonder te rillen) zoals we eerder deden bij de studies die net zijn besproken, konden we het bruine vet aanzetten en het met de PET/CT scan in beeld brengen.

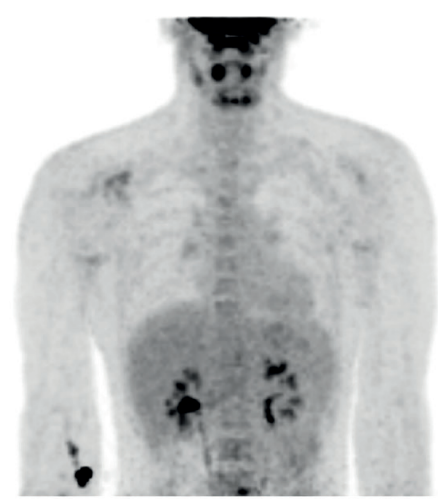

thermoneutraal

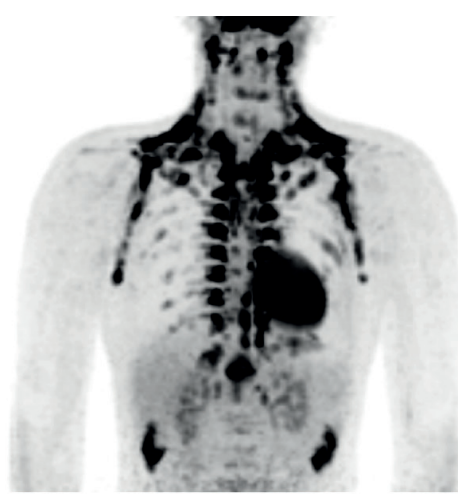

koele omgeving

Figuur 4. Resultaat van 2 PET scans bij dezelfde proefpersoon bij thermoneutraal en na afkoeling. Het zwart in de hals, bij de schouders achter het sleutelbeen en langs de wervels is het bruine vet. Verder zijn de hersenen en het hart (toevallig alleen bij de koele conditie) zichtbaar.

In figuur 4 is duidelijk te zien dat bij de vrijwilliger in de warmte (thermoneutraal) geen bruin geactiveerd is en in de kou het bruin vet zichtbaar wordt achter de sleutelbenen, in de hals regio en naast de wervelkolom. De werkelijke hoeveelheid bruin vet is waarschijnlijk minder, aangezien het weefsel dat zwart wordt weergegeven ook nog 
veel witte vetcellen bevat. De hoeveelheid bruin vet verschilt tussen de proefpersonen. Over het algemeen hebben mensen met overgewicht en ouderen minder bruin vet dan slanke jonge volwassenen.

$U$ heeft het gezien: $\mathrm{er}$ is een grote individuele variatie in warmteproductie in de kou en ook in de hoeveelheid bruin vet. Interessant is dat er een relatie is tussen de hoeveelheid bruin vet en de warmteproductie (figuur 5). Dus iemand met veel bruin vet heeft een grotere extra warmteproductie in de kou. Dat geeft aan dat bruin vet hierbij een rol speelt. Wat de werkelijke bijdrage is moeten we nog verder onderzoeken.

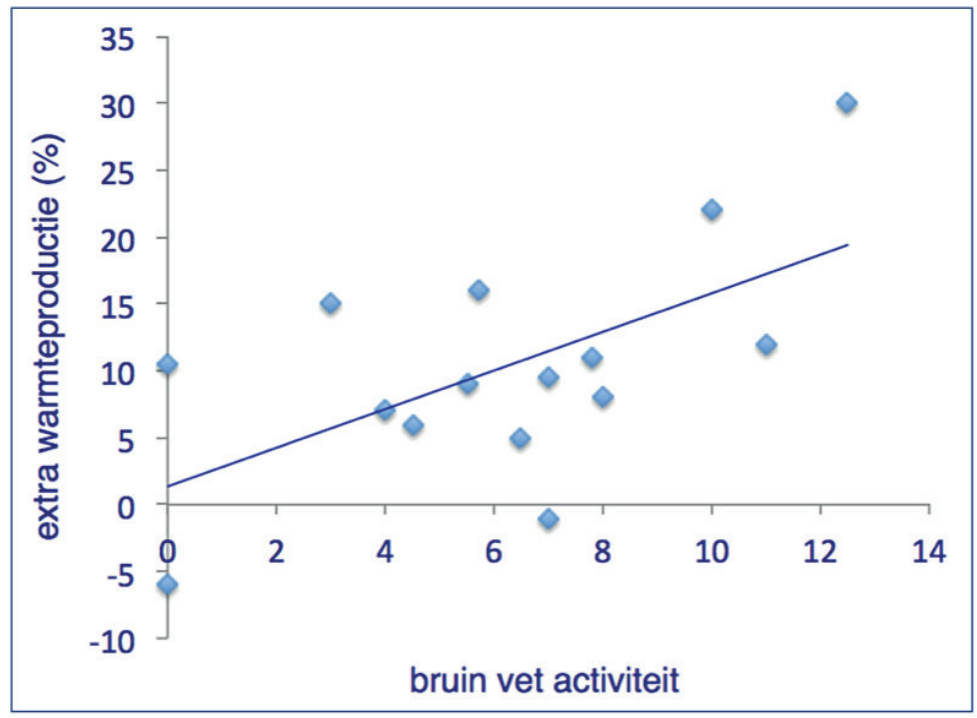

Figuur 5. De relatie tussen de extra warmteproductie in de kou zonder rillen en de bruin vet activiteit.

\section{Aanmaak bruin vet}

Maar als je weinig bruin vet hebt, kan je het dan vermeerderen? Met andere woorden, kan bruin vet worden aangemaakt en kunnen we daarmee ons energiegebruik verhogen? We zijn na de ontdekking van bruin vet niet stil blijven zitten en gelukkig, mede door Europese subsidies (Diabat-FP7) en die van NWO (ZonMW-TOP), in de gelegenheid geweest vervolgonderzoek te doen. We vroegen ons af of je, net als bij kleine dieren, door regelmatige blootstelling aan kou, bruin vet kan aanmaken. Promovendus Anouk van de Lans heeft vorig jaar voor het eerst laten zien 
dat bij jong volwassen mensen al na 10 dagen (6 uur per dag bij $14{ }^{\circ} \mathrm{C}$ ) de bruin vet activiteit omhoog gaat (van der Lans et al., 2013). Bij enkelen verdubbelde van de activiteit en volume van bruin vet zelfs. Opmerkelijk was dat de proefpersonen in deze 10 dagen al begonnen te wennen aan de kou. Wat ze aanvankelijk als oncomfortabel ervoeren was na tien dagen acceptabel. Met andere woorden: zelfs aan $14{ }^{\circ} \mathrm{C}$ raak je gewend! In feite is de comfortzone is breder geworden (figuur 6). Het maken van extra warmte zonder rillen blijkt redelijk comfortabel. We onderzoeken dit nu bij mensen met overgewicht, ouderen en mensen met suikerziekte.

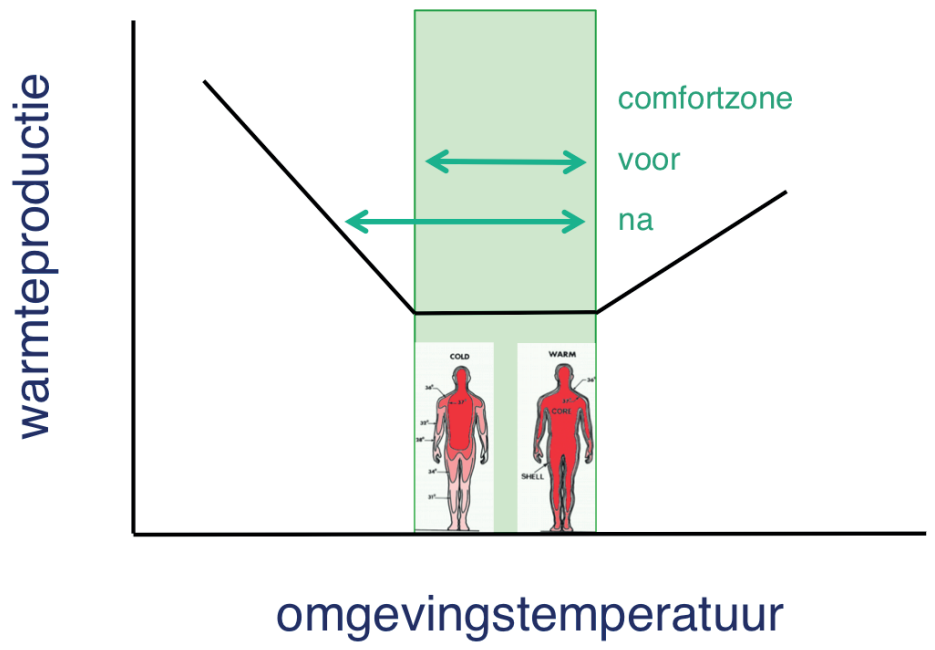

Figuur 6. De thermoneutrale zone en twee comfort zones; eenmaal vóór koude gewenning en eenmaal erna.

\section{Toekomst bruin vet onderzoek}

Hoe moet het nu verder met het bruin vet onderzoek? Waar gaan we ons de komende tijd op focussen?

1. Ik heb laten zien dat bruin vet te maken heeft met het energiegebruik. Maar uit dierexperimenten blijkt dat het ook een rol speelt bij het regelen van de vet- en suiker-huishouding van het lichaam. Promovendus Mark Hanssen doet momenteel onderzoek naar het effect van koude gewenning op bruin vet, energiegebruik en insuline gevoeligheid bij mensen met suikerziekte. Het ziet ernaar uit dat koude een gunstig effect heeft op de insuline gevoeligheid. Als na uitwerking van de resultaten dat werkelijk zo blijkt te zijn, dan gaan we daar verder onderzoek naar doen. 
2. Kou is de belangrijkste factor om bruin vet te activeren. Naast kou blijken ook andere factoren een rol te spelen. Promovendus Evie Broeders bestudeert het effect van schildklierhormoon en de effecten van galzuren op bruin vet activatie. Postdoc Mariëtte Boon begint binnenkort aan een vergelijkende studie naar de effecten van het eiwit L-arginine waarvan verwacht wordt dat het de hoeveelheid bruin vet kan vermeerderen bij Hindoestanen en Kaukasiërs.

3. Bruin vet hoeft niet in alle gevallen gunstig te zijn. Je kan er ook te veel van hebben. Teveel aan bruin vet zou kunnen leiden tot gewichtsafname, bijvoorbeeld bij bepaalde vormen van kanker. Binnenkort start in samenwerking met de vakgroep Pulmonologie en de afdeling Nucleaire Geneeskunde een studie naar kanker cachexie (d.w.z. extreem gewichtsverlies).

4. Met de huidige technieken kan nog niet precies worden bepaald wat de werkelijke bijdrage van bruin vet aan de warmteproductie is. Samen met Nucleaire Geneeskunde en Radiologie gaan we op zoek naar alternatieve technieken om de bruin vet bijdrage beter te kwantificeren. De net nieuw geïnstalleerde PET-MRI biedt daarvoor grote mogelijkheden.

5. Kou kan bijdragen aan gewichtsvermindering, maar er kan compensatie optreden. We kennen het van onszelf dat we, na een dag in de kou, flinke trek krijgen en gemakkelijk een boterham extra eten. Lange termijn effecten zullen dus zeker moeten worden bestudeerd. Ik denk dat die compensatie door meer voedingsinname niet zo erg hoeft te zijn. Met compensatie werkt het verhoogde metabolisme niet direct tot gewichtsreductie, maar wel tot een hoger energiegebruik en daarmee mogelijk tot een gezonder metabool profiel. In de toekomst wil ik dit verder bestuderen.

\section{Zuiver wetenschappelijk onderzoek}

Uit het onderzoek naar bruin vet blijkt dat je alert moet zijn op onverwachte resultaten. Wat dit aspect betreft moet me iets van het hart. Onze Medisch Ethische Commissie en ook de nationale en internationale subsidieverstrekkers dienen zich wat meer te realiseren dat je onderzoek doet omdat je iets nog niet weet! Ik vind dat er een duidelijker onderscheid gemaakt moet worden tussen klinisch toegepast en zuiver wetenschappelijk onderzoek. Door Medisch Ethische Commissies wordt naar mijn mening te veel nadruk gelegd op powercalculaties. Men eist in feite door het verplichten van het uitvoeren van powercalculaties 
dat je kan voorspellen wat de effectgrootte van je interventie is. Een voorstel om een aantal metingen te doen om gewoon te kijken of er iets onverwachts uit je proef komt rollen wordt al helemaal niet geaccepteerd. En toch, zo hebben we bruin vet ontdekt. Ik vind dat bovendien de statistische analyse van te verwachten uitkomsten niet van te voren in het onderzoeksvoorstel geheel vast moet worden gelegd, zoals dat bij klinisch geneesmiddelenonderzoek vaak wel noodzakelijk is. Dit onderscheid tussen 'clinical trials' en meer experimenteel onderzoek moet blijven, bij de beoordeling van Medisch Ethische Commissies en ook bij de steeds meer verplicht gestelde onderzoeks-monitoring.

\section{Thermische omgeving - binnenklimaat}

Nu wil ik met $u$ van de fysiologie van de mens naar zijn moderne omgeving, naar onze dagelijkse omgeving: huis en kantoor. Niet voor niets heet de leerstoel "Ecologische Energetica en Gezondheid". Ecologie is de studie van het organisme in zijn omgeving. Ecologische Energetica gaat over de energiewisseling, inclusief thermoregulatie, van het organisme (de mens) en zijn omgeving.

Ik streef ernaar dat de kennis die wordt opgedaan in het laboratorium kan worden benut in de dagelijkse leefomgeving. Zo belanden we weer op een kruispunt van kennisgebieden. Deze nieuwe benadering vindt geleidelijk aan erkenning in de wereld van de gebouwde omgeving (bouwkundigen, ingenieurs, architecten, bouwmaatschappijen, enz...). Er is veel gaande is in de gebouwde omgeving, met name op het gebied van betere isolatie, en het ontwikkelen van meer energiezuinige woningen en gebouwen. Volgens mij wordt er echter nog te weinig gebruik gemaakt van de kennis omtrent de fysiologie, de behoeften en de wensen van de gebruikers van die gebouwen.

Huidige richtlijnen in gebouwen betreffende de binnentemperatuur zijn gebaseerd op een model uit de jaren 70 en richten zich op het thermisch comfort van een gemiddelde mens (Fanger, 1970). Maar, zoals we hebben gezien, de gemiddelde mens bestaat niet. Het gebruik van dit model heeft geleid tot een uniform binnenklimaat (een temperatuur voor iedereen, de hele dag door, tijdens alle seizoenen, in diverse klimaatzones van de tropen tot de arctische streken). Dat leidt vaak tot klachten van de gebruikers over de temperatuur, maar ook tot hoge energiekosten. Bij dit klassieke comfort model zijn de temperaturen 's zomers en 's winters vrijwel hetzelfde (figuur 7). Bovendien worden de gebruikers zeer kritisch. Kleine afwijkingen lijden tot klachten. 
Meer recent is het zogenaamde adaptieve comfort model geïntroduceerd. Dat model houdt rekening met het feit dat individuen verschillen en dat mensen zich aanpassen aan een koele en warme omgeving en accepteren dat omgevingscondities variëren in de loop van het jaar en gedurende de dag (de Dear et al., 1998). Toepassing van dit adaptieve model resulteert in een meer dynamisch binnenklimaat. Dat leidt bovendien tot lagere stooken koelingskosten.

In het adaptieve model zijn echter fysiologische- en gezondheidsaspecten nog steeds niet opgenomen. Nieuw, geïnitieerd door onze onderzoeksgroep, is juist die link tussen binnenklimaat en gezondheid.

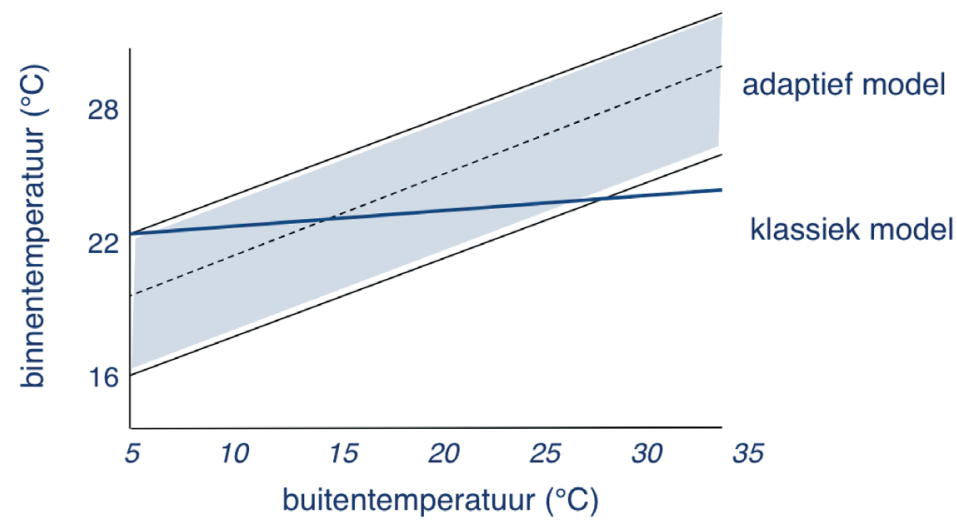

Figuur 7. Thermische comfort modellen voor gebruik in de gebouwde omgeving. Het klassieke model schrijft een uniform binnentemperatuur voor met weinig variatie. Dit leidt tot veel klachten. Het adaptief model houdt rekening met seizoenen en dagelijkse variatie waaruit blijkt dat mensen een grotere variatie in binnentemperatuur prefereren. De brede balk bij het adaptief model geeft de comfort range aan van $80 \%$ van de mensen.

Interessant zijn de studies van postdoc Lisje Schellen. Jong volwassenen en ouderen werden in een klimaatkamer van de afdeling Bouwkunde van de Technische Universiteit Eindhoven onderzocht. De temperatuur varieerde door de dag van 17 tot $25^{\circ} \mathrm{C}\left(17^{\circ}\right.$ om half negen 's ochtends, geleidelijk aan oplopend tot $25^{\circ} \mathrm{C}$ tussen de middag en dan weer zakkend naar $17^{\circ} \mathrm{C} \mathrm{om}$ 6 uur 's avonds) (Schellen et al., 2010). De meeste proefpersonen vonden deze variatie acceptabel, zelfs de ouderen. De binnentemperatuur hoeft dus niet zo constant te zijn als meestal wordt aangenomen. Bovendien kan de binnentemperatuur worden afgestemd op de buitentemperatuur. Door de temperatuur binnen te laten meebewegen met de buitentemperatuur 
kan veel energie worden bespaard. Dit is acceptabel en waarschijnlijk nog gezond ook.

Dit soort gegevens heeft geleid tot een nieuwe praktische benadering over onze omgeving, ons binnenklimaat. Is het niet beter om wat variatie in die temperatuur aan te brengen, zodat we af en toe ons lichaam moeten laten werken om warm te blijven en wat bruin vet aan te spreken? Daar willen we de komende jaren onderzoek naar doen. Niet alleen in het lab, maar ook thuis en op kantoor.

Er zijn plannen voor een nieuw te bouwen centrum, Mosae vita, bij onze universiteit op de "Health Campus". Gezonde mensen uit Zuid Limburg, patiënten, verplegend personeel, onderzoekers en studenten komen hier bij elkaar in één gebouw. Er komen een bewegingslaboratorium en een restaurant waar je leert gezond te koken. Er komt ook een speciale klimaatkamer en in diverse verblijfruimtes kan straks met temperatuur en licht worden geëxperimenteerd. De ideale setting dus om in de praktijksituatie de effecten van de omgeving op herstel van ziekte en gezondheid te testen.

\section{Vakantietemperaturen}

Tenslotte nog één uitstapje. Zijn we wel gelukkig in onze o zo comfortabele omgeving? Het lijkt erop van niet. Als het vriest gaan we schaatsen. Waar gaan we naartoe, met busladingen vol? Naar de bergen om te skiën in de ijzige kou! Daar genieten we. Natuurlijk genieten we van het skiën zelf, maar ook van de kou. Heerlijk die frisse berglucht. Meer dan comfortabel. $\mathrm{Na}$ de kou genieten we van de warmte, liefst bij een open haard. Pret bevindt zich buiten de comfortzone. De variatie doet er toe.

's Zomers hetzelfde: bakken op het strand, afkoeling in het water. Heerlijk. Als we daar weer iets van terug kunnen brengen in huis en op kantoor dan worden we gezond en nog gelukkig ook.

\section{Toekomst onderzoek binnenklimaat}

1. Ik heb de effecten van koude gewenning laten zien. Maar hoe zit het met gewenning aan warmte in het dagelijks leven? Dat is relevant in verband met de geleidelijke toename van warme periodes als gevolg van de klimaatverandering. Hier is nog heel weinig over bekend. Er zijn alleen gegevens van meer extreme condities en bij lichamelijke inspanning. Promovendus Hannah Pallubinsky start daarom binnenkort een studie naar de effecten van het wennen aan warmte, zoals we dat ook voor koude hebben uitgevoerd. Wie weet wat voor ontdekkingen ons te wachten staan. 
2. Er zijn aanwijzingen dat licht ons thermisch comfort en de temperatuurregulatie kan beïnvloeden. In samenwerking met Philips is promovendus Marije te Kulve onderzoek gestart in de interactie tussen LED licht condities en thermisch comfort.

3. Cruciaal is dat we meer te weten komen over het thermisch gedrag van bewoners thuis en op kantoor. We gaan dat gedrag beter in kaart brengen. We zijn al gestart met het ontwikkelen van individuele comfortsystemen op kantoor, in samenwerking met de industrie (het project UCER), en om de invloed van de gebruiker op het functioneren van gebouwen in kaart te brengen (project TRECO). Deze projecten worden ondersteund door het ministerie van Economische Zaken, via het programma Top Kennis en Innovatie (TKI). Er wordt samengewerkt met partners uit de industrie, andere universiteiten en ingenieursbureaus en ik ervaar dat als zeer stimulerend.

Om werkelijk een slag te maken moeten de onderzoeksgegevens vertaald worden in modellen die kunnen worden ingezet in de gebouwde omgeving. Samen met Dr. Arjan Frijns van de Technische Universiteit Eindhoven werkt postdoc Boris Kingma aan een thermofysiologisch model (ThemoSEM). Thermisch comfort en thermisch gedrag zullen ook worden gemodelleerd. Vervolgens kan het model worden gekoppeld aan de eigenschappen van het gebouw.

\section{Ter afsluiting}

Ik hoop dat $u$ nu begrijpt dat het buiten de comfort zone niet per sé onaangenaam is en zelfs gezond kan zijn. Een beetje kou lights your fire! Door een wisseling in temperatuur wordt het lichaam aangesproken. Zoals lichaamsbeweging gezond kan zijn, zo is een variatie in temperatuur dat ook. We zouden kunnen spreken van temperatuur training. Het lichaam moet in de kou en ook in de warmte een beetje meer werken. En dat beetje meer werken creëert een gezonder en weerbaarder lichaam. Met name ouderen zijn erg kwetsbaar. Maar ze worden ook kwetsbaar gemaakt door in zorgcentra een constante (in de winter een veel te hoge) temperatuur te handhaven. Juist meer variatie in temperatuur kan ervoor zorgen gezonder en weerbaarder oud te worden.

Al met al zullen de effecten niet groot zijn voor elk individu, maar met subtiele effecten van een gezond binnenklimaat bereik je wel grote delen van de bevolking en daarmee kunnen de effecten op populatieniveau aanzienlijk zijn. 


\section{Onderwijs: een nieuwe Master}

Bij het ontwerpen van een gebouw komt meer kijken dan wat ik besproken heb over binnentemperaturen. Andere factoren in onze omgeving bepalen mede onze gezondheid: licht, geluid, luchtkwaliteit, luchtvochtigheid. Daarnaast spelen mee de beschikbaarheid van voeding en mogelijkheden om je te bewegen. Deze aspecten zouden in het ontwerp niet mogen ontbreken.

In samenwerking met de Hogeschool Zuyd onder leiding van Prof. Jos Ligtenberg zijn we een nieuwe multidisciplinaire Master aan het opzetten. Daarin integreren beide kennisvelden: Bouwkunde en Gezondheidswetenschappen. Deze gebieden tezamen zullen studenten opleiden die ingezet kunnen worden in het creëren van duurzame én gezonde kantoren en huizen.

\section{Dankwoord}

Aan het eind van mijn rede gekomen wil ik graag een aantal mensen bedanken die hebben bijdragen aan mijn carrière en mijn benoeming. Ik dank het College van Bestuur van de Universiteit Maastricht en de Raad van Bestuur van Faculty of Health, Medicine and Life Sciences, evenals de leden van mijn benoemingscommissie, voor het in mij gestelde vertrouwen. Ook alle medewerkers van de vakgroep Humane Biologie dank ik voor de hartelijke steun. Met name wil ik noemen de secretaresses, Desiree Morales, Claudia Pachen en Yolanda Verhaegen en de technische inventiviteit van Paul Schoffelen en Loek Wouters. Professor Wim Saris wil ik bedanken voor de plezierige samenwerking. In het bijzonder wil ik Professor Ronald Mensink en Professor Annemie Schols bedanken voor de steun en het vertrouwen in het traject naar deze leerstoel. Speciale melding verdient Sef Janssen, algemeen directeur van NUTRIM. Hij heeft me veel geholpen bij het indienen van aanvragen voor subsidie en samen met zijn team is het regelen van de financiën en juridische aspecten van projecten een plezier. Van Wil Botden van het loopbaancentrum heb ik veel betrokken ondersteuning gekregen.

Ik heb reeds genoemd mijn promotor wijlen Professor Rudi Drent. Hij heeft me geïnspireerd tot het doen van eco-fysiologisch onderzoek. Het dier in zijn omgeving. De interactie tussen dier en omgeving is wederzijds; twee kanten op. Dat samenspel, ook bij de mens, is wat me nog steeds boeit. Ik ben gegaan van het buitenklimaat (leguaan) naar het binnenklimaat (de mens), maar ik kan nog steeds dezelfde soort vragen stellen. En als ik me die vragen stel, denk ik aan hem. 
Geleidelijk aan heb ik een team van promovendi en postdocs kunnen formeren. Zonder hun inzet en die van vele stage studenten stond ik hier niet. Speciale dank aan de (ex-) promovendi Sander Wijers, Guy Vijgen, Maarten Vosselman, Anouk van der Lans, Mark Hanssen, Evie Broeders, Hannah Pallubinsky en Marije te Kulve. Jullie houden me scherp en bovenal houden jullie me buiten de comfortzone en dus gezond!

Ik ben ook gezegend met drie gemotiveerde postdocs. Met elk een duidelijk signatuur steunen zij mij volop in deze tijd van steeds vollere agenda's. Lisje Schellen: mijn steun en toeverlaat bij de projecten met een link naar de gebouwde omgeving. Zij vertelt me wie ook alweer wie is op congressen en samen komen we op mooie nieuwe ideeën om onze labkennis in te zetten in kantoren en huizen. We werken gezamenlijk aan de nieuwe master over de gezonde gebouwde omgeving. Boris Kingma, vriend en collega, ik ben blij dat je weer terug bent in onze groep. Je hebt een verassend veelzijdige kijk op onderzoek (en het leven). Ik hoop op nog heel veel "werk"-overleg met inspirerende onverwachte wendingen. Je capaciteit om kennis en processen om te zetten in modellen is van grote waarde en ik hoop dat men binnen de gezondheidswetenschappen meer van het nut van modelleren doordrongen raakt. Mariëtte Boon, de laatste postdoc en telg van het team. Ik ben blij dat je ons vergezelt en met je aanwezigheid de samenwerking met de onderzoeksgroep van Professor Patrick Rensen van de Universiteit van Leiden vorm geeft.

Patrick Schrauwen, collega en vriend, je verdient een aparte vermelding. Je was m'n eerste promovendus. Je bent wat sneller dan ik en al enige jaren hoogleraar. Dat vond ik niet erg, integendeel, ik genoot en geniet er van omdat je je zo inzet voor goed onderzoek. In moeilijke tijden ben je een grote steun voor me geweest. Ik ben daarom heel blij dat ik weer volop met je samenwerk. Waar ik soms mijn eigen resultaten wat bagatelliseer, zie jij de waarde er van in. Ik heb veel te danken aan jouw inzet en inzicht. Ik hoop nog jaren met je samen te werken.

Vermeldenswaard is de goede samenwerking met Nucleaire Geneeskunde. Ik heb al genoemd emeritus hoogleraar Jaap Teule, die met z'n aanstekelijke enthousiasme me inspireerde het bruin vet onderzoek te starten. Tegenwoordig staat Nucleaire Geneeskunde onder leiding van Professor Felix Mottaghy, die het bruin vet onderzoek van harte ondersteunt. Bijzonder blij ben ik met de samenwerking met Dr. Boudewijn Brans, zowel voor de dagelijkse gang van zaken als de interpretatie en analyses 
van de scans. Graag wil ik ook Dr. Nicole Bouvy van Algemene Heelkunde bedanken voor de plezierige samenwerking. Zij hielp ons aan het eerste stukje bruin vet weefsel, waarna er vele volgden.

Zonder te pretenderen volledig te zijn wil ik een paar mensen bedanken die betrokken zijn bij het werk aan de gebouwde omgeving. Allereerst Peter Op't Veld, van het ingenieursbureau Huygen Installatie Adviseurs, die als eerste uit de bouwwereld het belang zag van de link tussen ons fysiologisch werk en de gebouwde omgeving.

Ons onderzoek aan de gebouwde omgeving wordt deels gefinancierd door de Rijksdienst voor Ondernemend Nederland (RVO). Vanuit die instelling was Piet Heynen betrokken. Hij heeft ons bij de soms gecompliceerde multidisciplinaire studies enorm ondersteund.

De samenwerking met Anton van Steenhoven van de TUE heb ik zeer gewaardeerd. Anton is een groot inspirator en een zeer betrokken mens. Gelukkig kan ik de samenwerking met zijn collega Dr. Arjan Frijns voortzetten.

Dr. Luc Schlangen van Philips wil ik van harte bedanken voor zijn grote inzet in het nieuwe STW-partnership project.

Samen met Professor Hein Daanen en Professor Eus van Someren heb ik zo'n tien jaar geleden ThermoNED opgericht. Dat is een jaarlijkse bijeenkomst van Nederlandse thermofysiologen. Inmiddels zitten we met ruim 40 onderzoekers om de tafel en delen enthousiast onze studies.

Ik denk nog veel aan mijn ouders. Ik weet dat mijn vader heel trots zou zijn geweest en mijn moeder heb ik nog net kunnen vertellen dat ik hoogleraar werd. Ze vond het fantastisch. Aan allebei ben ik veel dank verschuldigd voor de mogelijkheden die ze me geboden hebben. Ik herinner me dat aan de eetkamertafel mij, toen ik een jaar of 7 was, een keer gevraagd werd wat ik wilde worden. Hoewel ik voorheen het liefste loodgieter wilde worden, antwoorde ik toen: professor in de weet-nietkunde. Dat is me nooit gelukt. Maar ik ben nu wel hoogleraar Ecologische Energetica en Gezondheid. Dankzij mijn ouders.

Lieve Anne en Merel. Mijn thuisfront en mijn onvoorwaardelijke steunen. Dank jullie wel voor alle geduld. Terwijl ik voorheen Merel hielp met schoolwerk, hielp zij me nu met m'n oratie! Wat een feest, zo'n dochter! Anne, mijn lieve levensgezellin; altijd sta je voor me klaar. Woorden schieten te kort.

Ik heb gezegd. 


\section{Literatuur}

de Dear R, Brager GS (1998). Developing an adaptive model of thermal comfort and preference. ASHRAE Transactions 104(1): 145-167.

Fanger PO (1970). Thermal comfort. edn. Danish Technical University: New York.

Kingma B, Frijns A, van Marken Lichtenbelt W (2012). The thermoneutral zone: implications for metabolic studies. Front Biosci (Elite Ed) 4: 1975-1985.

Schellen L, van Marken Lichtenbelt WD, Loomans MG, Toftum J, de Wit MH (2010).

Differences between young adults and elderly in thermal comfort, productivity, and thermal physiology in response to a moderate temperature drift and a steady-state condition. Indoor air 20(4): 273-283.

Scholander PF, Hammel HT, Hart JS, LeMessurier DH, Steen J (1958). Cold adaptation in Australian Aborigines. J Appl Physiol 13: 211-218.

van der Lans AA, Hoeks J, Brans B, Vijgen GH, Visser MG, Vosselman MJ, et al. (2013). Cold acclimation recruits human brown fat and increases nonshivering thermogenesis. The Journal of clinical investigation 123(8): 3395-3403.

van Marken Lichtenbelt WD (1991). Energetics of the green iguana (Iguana iguana) in a semi-arid environment. edn, vol. PhD thesis. State University of Groningen.

van Marken Lichtenbelt WD, Vanhommerig JW, Smulders NM, Drossaerts MAFL, Kemerink GJ, Bouvy ND, et al. (2009). Cold-activated brown adipose tissue in healthy adult men. New Engl J Med 360(15): 1500-1508. 


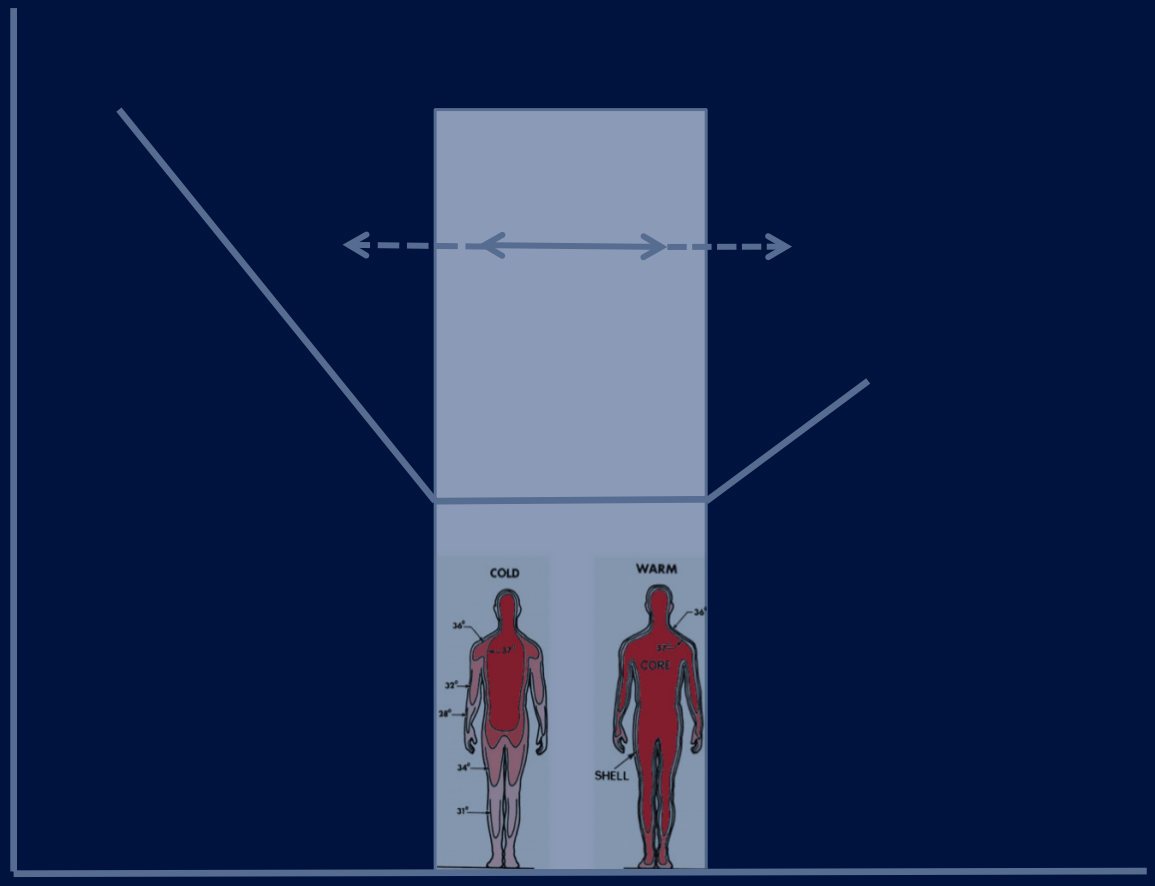

